\author{
Marta Galant \\ Dr inż. \\ Politechnika Poznańska \\ Marta.galant@put.poznan.pl
}

DOI: $10.35117 / A \_E N G \_18 \_12 \_09$

\title{
Analysis of the possibilities of general aviation safety increasing through the use of new technologies
}

\begin{abstract}
The paper presents an analysis of the current state of aviation safety in Poland and an assessment of the possibility of its improvement. It has been pointed out that the specificity of general and commercial aviation practically does not allow their joint treatment in security management. The SHELL concept and the proposal to develop it for use in the design of security systems were discussed. This allowed to indicate the security systems application possibilities. Sequentially potential benefits of the proposed implementation of technology in general aviation were analyzed. The article is summarized by application conclusions which are also the future directions of the development of safety management in general aviation.
\end{abstract}

Key words: Safety; Air transport; General Aviation

\section{Introduction}

A sense of security is one of the basic human needs. Such a location in the pyramid of needs leaves no doubt as to the rightness of continuous work to increase it and such impact on the sources of threats so that the estimated risk is acceptable. Air transport is constantly the fastest growing branch of transport $[8,13,15]$. It is also considered to be the safest way of moving [11]. Analyzing the statistics of aviation accidents in commercial transport, you can actually reach such conclusions. However, good results achieved in commercial air transport (called Commercial Air Transport, CAT) are not reflected in the second, the equally significant part of aviation that is General Aviation (GA). About 200,000 GA operations and about 350,000 operations related to passenger transport are performed every year in Poland [1]. In addition, these numbers increase by around $10 \%$ each year. All this indicates that the works discussed in this study are necessary, and the use of new technological achievements is necessary to achieve the assumed goals.

\section{The state of aviation safety depending on the type of aviation}

The main authority responsible for the safety of air transport in Poland is the Civil Aviation Office (Urząd Lotnictwa Cywilnego - ULC). He is responsible for the implementation of regulations governing aviation activities in the country. The Office for Safety Management in Civil Aviation was established within the ULC. His tasks include supervising, coordinating and managing matters related to civil aviation safety management, including in particular the creation, updating and coordination of the National Civil Aviation Safety Program (KPBwLC). The CAO, however, does not conduct safety investigations. For this purpose, in 2002 an independent and permanent State Commission on Aircraft Accident Investigation (PKBWL) was set up. The Commission operates under the minister responsible for transport (from 2011 Ministry of Infrastructure and Construction). The Commission annually publishes Aircraft Accident Statistics [10], which is presented at the National Flight Safety Conference organized by the Civil Aviation Authority. The Aviation Act among types of aviation occurrences distinguishes accidents, serious incidents and incidents [16]. An air accident is an event related to the operation of an aircraft that has occurred since any person entered it with 
the intention of flight until all persons on board have left that aircraft and during which: any person She suffered life-threatening injuries or serious bodily injury, the aircraft was damaged or the structure was destroyed or the aircraft was lost or in a place where access is impossible [16]. A major aviation incident is an event whose circumstances indicate that an accident has almost occurred [16]. An incident is an incident other than an aviation accident related to the operation of an aircraft that affects or could affect its safety [16]. In the GDPWL reports, this nomenclature is retained. In 2017, the GDPWL registered 3344 aviation accident reports, of which 91 were classified as accidents, 28 as serious incidents, 1305 as incidents and the remaining 1920 as other notifications [10]. Comparing the data for 2016, the number of accidents decreased by $16 \%$, and the number of serious incidents by almost $40 \%$. The number of incidents has decreased by more than $40 \%$. On the other hand, there was a significant increase in the share of other applications - it increased fourfold! (Fig. 1). In the general aviation sector in 2017, 616 applications were registered [10]. In comparison to 2016, in which the number was 734 , a 16\% reduction was recorded (Figure 1).

a)

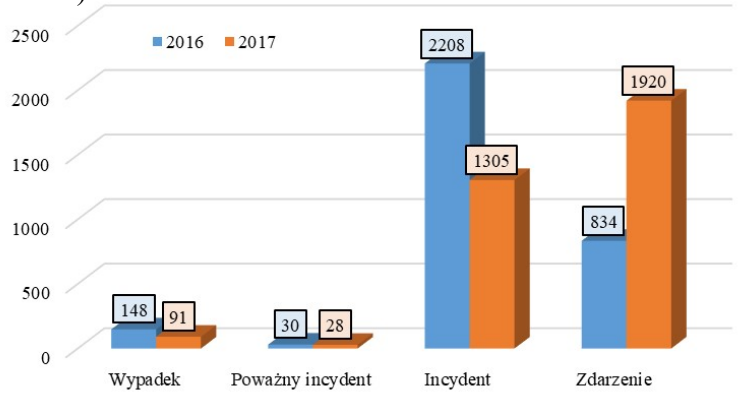

b)

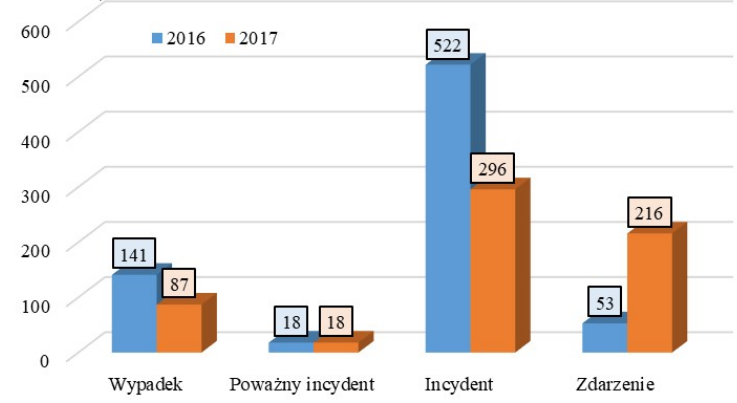

1. Number of aviation events (broken down by categories) in Poland in 2016-2017, where: a) total number of events, b) number of events in the general aviation sector; own elaboration based on [10]

As in the case of the total number of aviation incidents, the number of accidents decreased by approximately $40 \%$. Again, the number of incidents decreased by almost a half, and the number of other events increased fourfold. Comparing the number of accidents in the general aviation sector to the total number of accidents, it can be noticed that in 2016 their ratio is $95 \%$ annually. In turn, the number of incidents and other events presents an inverse relationship - in 2016, events and incidents in the GA accounted for 19\%, in 2017 - 16\%.

The increased number of reports is caused by the implementation and compliance with the obligations arising from the KPBwLC. It describes the methods of ensuring security, understood as a compulsory air accident reporting system (for aviation entities) and a voluntary and confidential reporting system affecting civil aviation safety (for airspace users). The first of the systems impose on air operators the obligation to report to the PKBWL occurring events consisting in a break in operation, defect, damage to the aircraft or its element or other circumstances that had or could have an impact on flight safety. Reporting such an event should be made to PKBWL within 72 hours from the moment of occurrence [9]. In order to improve the system of compulsory reporting, a provision was introduced in the Aviation Law [16], which prohibits discrimination against employees who submitted a report (Article 135a (5) of the Act). An additional safeguard is a provision stating that the criminal proceedings are not initiated against infringements of the law committed unintentionally (except in cases of gross negligence). The analysis of reported events allows for the development and updating of the National Safety Plan. The confidential reporting system affecting civil aviation safety is maintained by the Civil Aviation Identification Team at ULC. It was established in 2008 under the announcement of the President of the CAO on the 
introduction of a voluntary and confidential reporting system affecting the safety of flights in civil aviation (Official Journal of ULC No. 14 of 2008). The basic assumption of the Team's operation is that through it the information from the aviation environment should be collected, which will allow identifying potential areas of threats to the safety of aviation operations.

However, attention should be paid to the difference between the number of applications between the general and commercial aviation sectors. In this first case, there are 7 applications for one flight accident. In commercial aviation, this ratio is 682: 1 (out of 4 aviation accidents there were 2728 applications). This proves the effectiveness of the implemented safety management system in aviation organizations (SMS). Commercial aviation is characterized by greater security awareness. The implemented programs bring tangible results thanks to the promotion of safety, training and conducting activities aimed at increasing the level of security. In general aviation, there is much greater dispersion of users. Many pilots are not associated with aeroclubs and air operations are performed only for recreation. This means that they are not a legal aviation entity and have no obligation to develop, implement and comply with SMS rules.

In addition to lesser safety awareness, it is very important to pay attention to the changing ratio of individual events in Polish aviation. Figure 2 shows the change in the number of individual events in the last 5 years. A favorable phenomenon is a reduction in the number of fatalities. However, the worrying decrease in the number of incidents to other events is a concern. The unclear procedure for qualifying events by PKBWL leaves uncertainty about the current state. Determining events as "other, not affecting safety" may cause some kind of drowsiness of vigilance and limitation of focus on eliminating sources of danger. Such actions can have significant negative consequences in the future.

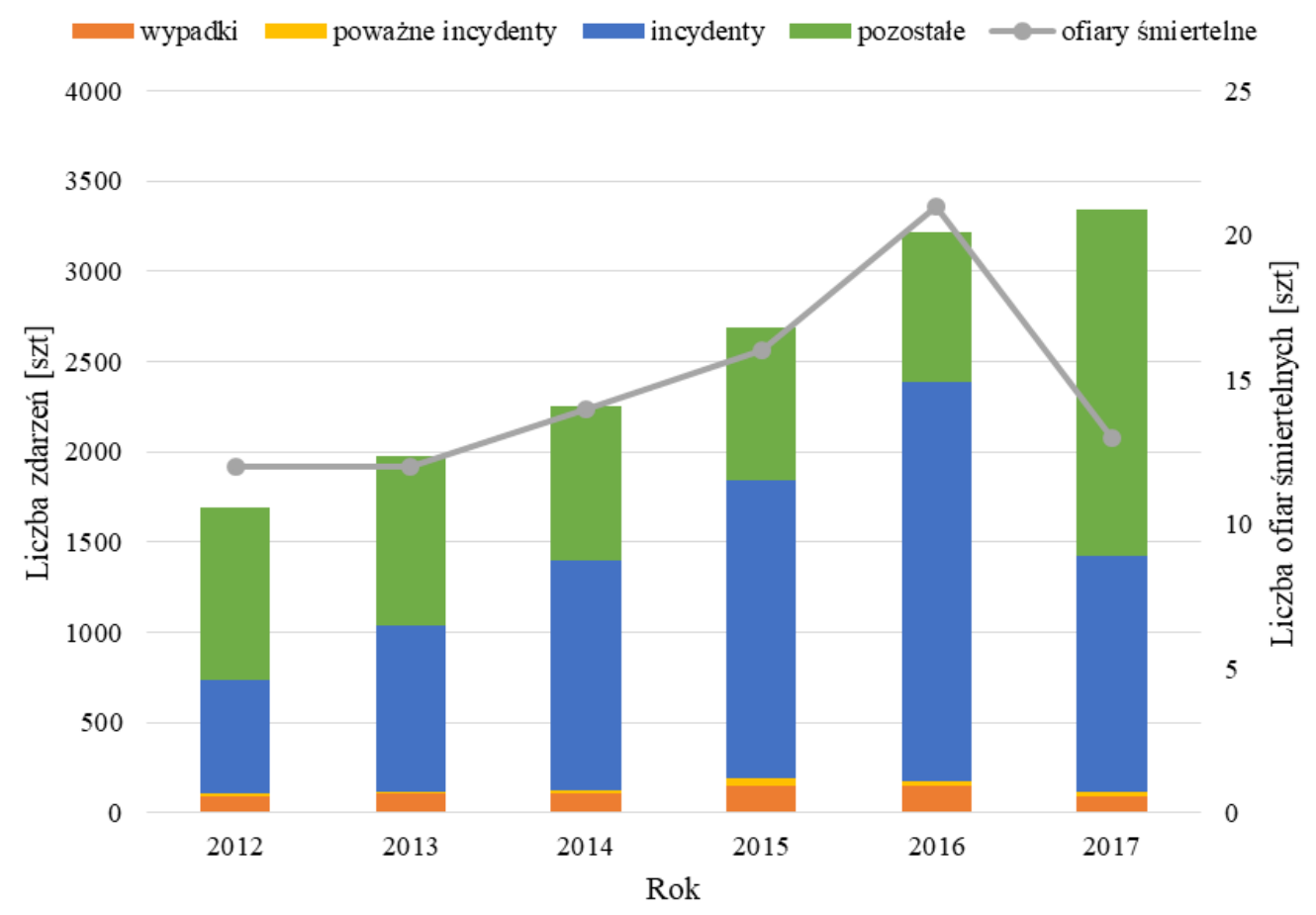

2. Number of aviation incidents in Polish aviation in the last 5 years; own elaboration based on [10] 


\section{Possibilities of influencing safety in general aviation}

The SMM manual recommends the identification of hazards based on the SHEL model (sometimes referred to as SHEL (L)) [7]. The SHELL model is a conceptual tool used to analyze the interaction of various system components. The name SHEL (L) comes from the first letters of the constituent parts, which means [12]:

- Software, S - concerns procedures, training, etc.,

- Hardware, $\mathrm{H}$ - refers to machinery and equipment,

- Environment, E - refers to the operational context in which the L-H-S system operates,

- Liveware, L - concerns people in the workplace.

The schematic diagram of the SHELL system model is presented in figure 3 . This model places emphasis on individual and human contact points with other components and system features.

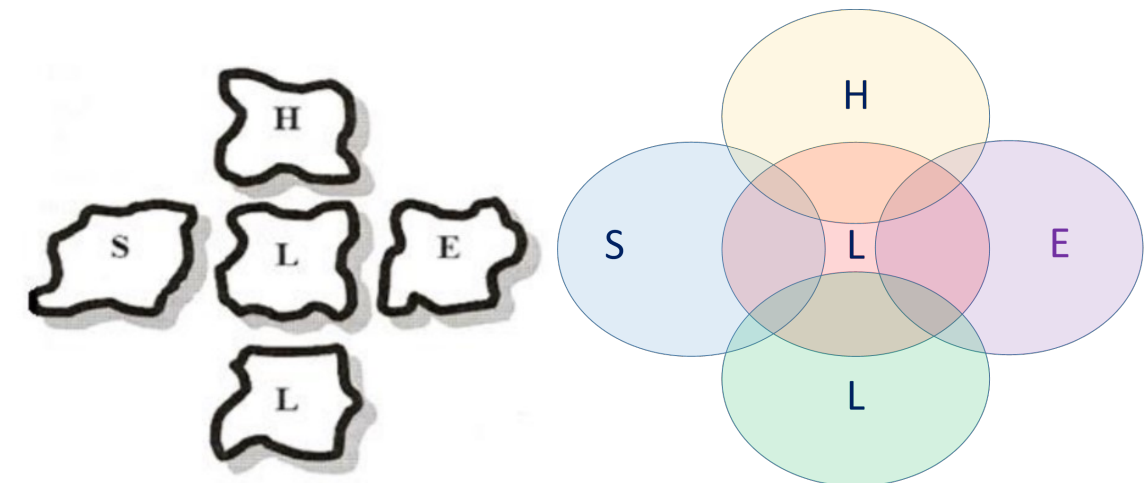

3. The schematic diagram of the SHELL $[2,6]$ model and the proposal to extend the model with additional areas of impact

Visual representation of the model as matching elements can symbolize that the system is fully functional with the appropriate combination of components - successively S-L, L-H, L-E, and L-L. However, attention should be paid to the comprehensiveness and complementarity of air transport systems. In addition to the contact of individual elements (S, $\mathrm{H}, \mathrm{E}, \mathrm{L}$ ) with the human factor L (remote control), it is also necessary to influence direct connections between them (e.g. S-H) as well as three-way systems (S-L-H). Only this approach to the construction of security systems will allow the introduction of solutions that can positively affect the reduction of the risk of threats in general aviation.

For example:

- S-H area and S-L-H assembly can be determined between factors S and H. In the first of them, it is important to combine the provisions with the equipment in use. There are a number of regulations regarding the certification, review and operation of air transport, however, acting in accordance with the adopted principle, it is important to combine factors $\mathrm{S}, \mathrm{H}$ and $\mathrm{L}$ - that is, develop procedures to be transparent and effective.

- proactive approach to safety management

- factor $\mathrm{H}$ is in the vicinity of factor $\mathrm{E}$ - this determines the areas of HL (human cooperation with the aircraft), EL (environmental impact on human - temperature, lighting, noise, visibility, turbulence, terrain) but also a new ELH area in which it is necessary to combine the human-technology-environment system so that it is possible to reduce the risk of threats. An example of such an operation may be a pilot assist system in the event of deterioration of external conditions.

- another example is the L-L-E area, i.e. the cooperation of the pilot, people around him and the environment. The key activity allowing to limit the risk in this area may be the 
extension of training in the field of CRM (Crew Management Management) but also the monitoring system of the psychophysical condition of the pilot, which is the subject of further analysis at work.

In each of the areas, a number of threat sources can be defined, which in turn can activate threats leading to the occurrence of adverse events. The key to reducing the risk of threats is, therefore, influencing the sources of threats before the threat is activated. This approach is in line with the current tendency to use proactive security management methods (instead of reactive methods used in the past).

\section{Pilot status monitoring as a tool to increase safety in aviation}

As mentioned in the previous chapter, one should look for solutions combining various elements of the analysis area which is air transport. The number of tasks performed by the operator causes an increase in the cognitive load, which uses its resources needed for the proper performance of the task, so-called cognitive resources. The concept of cognitive load refers to the degree of involvement of cognitive resources in the current activity of the subject [4]. One of the possible and effective methods to reduce the risk of threats in which one of the sources of danger is an excessive burden on the operator's cognitive system is its ongoing monitoring.

Cognitive load tests can be divided into four groups according to the character (Figure 4): subjective, objective, behavioral and based on the means of transport [4, 14]. The first of them are based on the subjective assessment of the load by the subject and are implemented in the form of tests or questionnaires. For research purposes, objective methods are used more often. They are related to the measurement of physiological parameters regardless of the operator (e.g. the bioelectric activity of the brain or blood oxygenation).

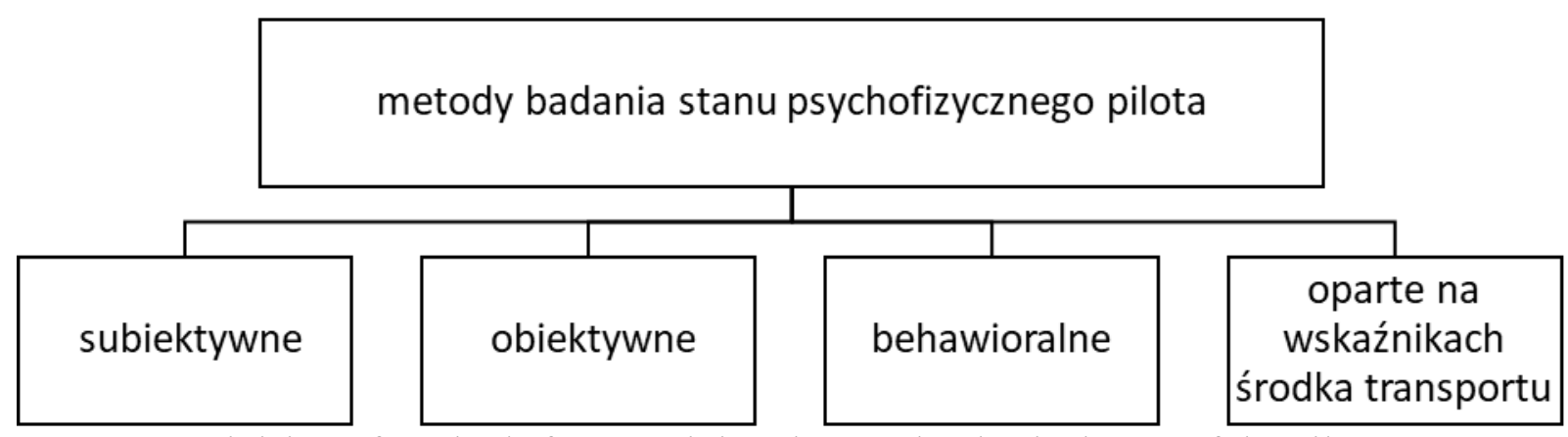

4. Division of methods for examining the psychophysical state of the pilot [4]

Behavioral methods mean detection of load symptoms such as yawning, closing eyes, too long saccades (intense eyeball movements, involving a very fast movement of the point of concentration of sight from one place to another) or fixations (relatively constant position of the eyeball, during which focusing takes place) comments). In turn, determining the operator's inefficiencies based on vehicle indicators is, for example, monitoring steering wheel movements, steering, maintaining the appropriate parameters (position at the road lane, set flight altitude)).

\section{Implementation of the security system - applications}

To determine the risk level of threats, a procedure must be followed in accordance with the risk management algorithm. It is, therefore, necessary to initially identify and define the area of analysis, identify sources of threats in turn and formulate threats based on them. Assigning them the right quantities allows you to estimate the risk which completes the stage of its analysis. The next step is the risk assessment based on its evaluation and categorization 
(acceptable, tolerated, unacceptable risk). After assessing the risk, the risk is followed. This means taking an active attitude to the threats identified in the area of transport system analysis and the risk they generate. This applies to threats from tolerable and unacceptable categories. In the case of accepted threats, the response is limited to risk monitoring.

In order to assess the impact of the use of technology on safety in general aviation, the analysis area was defined as the flight of general aviation aircraft in the uncontrolled space in accordance with the provisions for flights with visibility. In the analyzed area, 37 threats were identified, of which 15 were categorized as tolerated and 6 as unacceptable [4]. Therefore, the paper [4] proposes a system design whose creation, implementation and use may result in lowering the level of risk.

Assuming that the psychophysical state of the pilot, which is indirectly understood as his psychophysical efficiency, can be monitored, and the effects of its reduction leveled by the system supporting his work, it was possible to reduce the value of some parameters (for hazards in which poor psychophysical condition was recognized as a source pilot). Based on the risk analysis, it was noticed that up to $80 \%$ of defined threats threaten the condition of the pilot is one of the sources of danger.

Therefore, in order to verify the implementation of the system, it was decided to assign the parameter values again, with the assumption of correct system operation. It was considered that it is impossible to influence the level of losses resulting from the threat's activation. It was decided to analyze the possibility of reducing the probability level of the event.

The application of this assumption allowed to reduce the probability level of threat activation for fourteen threats. In total, the risk cognizance for nine threats was reduced (Figure 5). After implementing the system, the risk of threats was reduced. Its re-evaluation indicated that 27 threats belong to the accepted category, 6 classified as tolerated and 6 as unacceptable.

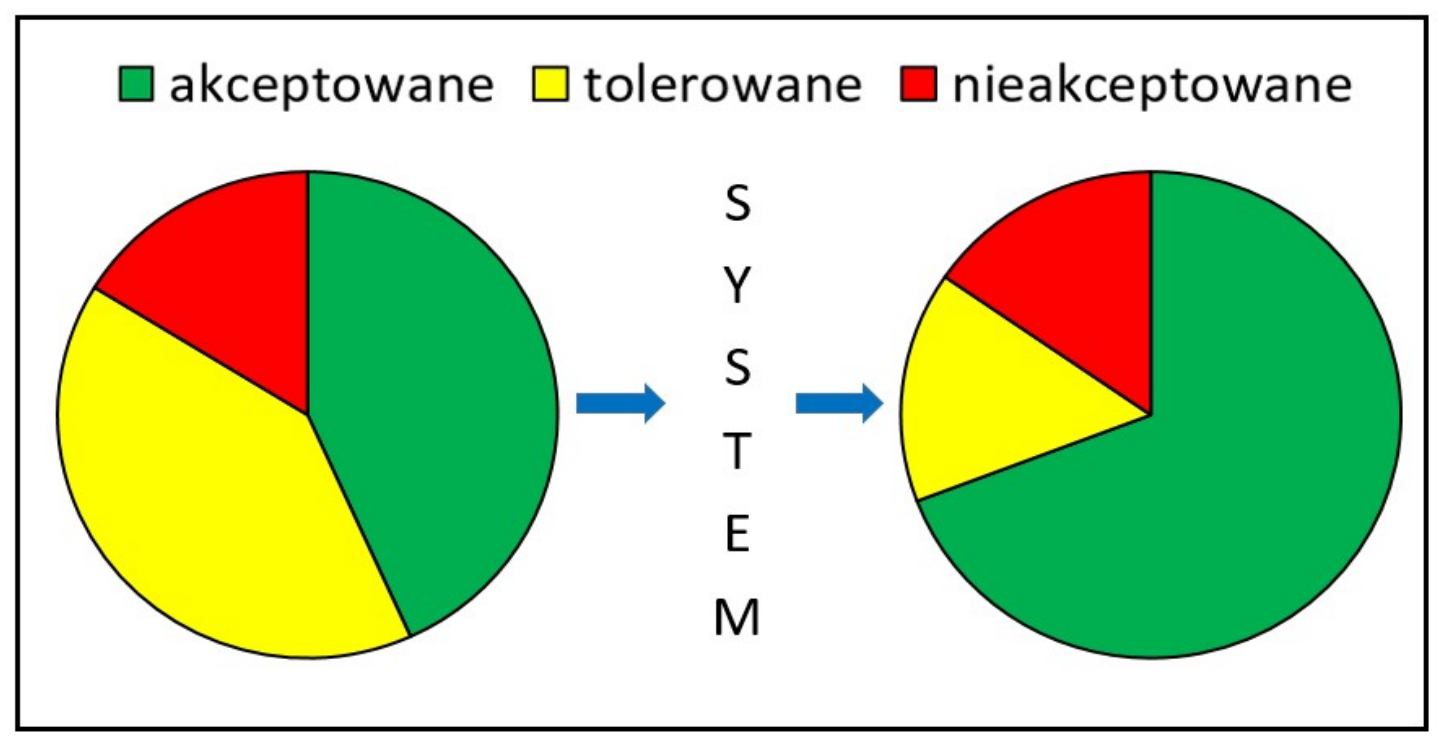

5. Comparison of the results of risk assessment before and after application of the analysed system [4]

Analyzes have shown that the implementation of the psycho-physical monitoring system presented in [4] and supporting its work in a situation of cognitive deficits may contribute to the reduction of risk in 14 of 37 (about 40\%) previously formulated threats. 


\section{Summary}

General aviation (GA) is becoming more and more popular. It is characterized by a very large variety of forms - from business flights, through scenic, to recreational. Therefore, the identification of hazard sources should be carried out in narrow areas of analysis, taking into account the different specifics of the activities performed.

The analysis in this work concerns the element of the safety management system, in the form of the issue of dealing with the risk of threats to the adopted area of analysis, which is the flight of general aviation aircraft in the uncontrolled space carried out in accordance with regulations for flights with visibility. The expression of this procedure is, among others establishing and researching appropriate security systems, enabling reduction of risk of threats in demanding areas. As an example of such a system, a system was proposed for monitoring the psycho-physical state of the pilot and supporting his actions in the situation of a shortage of cognitive resources over real time. Therefore, the effects of introducing such a system were estimated and it was shown that it is possible to reduce the risk of threats.

The presented considerations confirm the thesis regarding the existence of differences in the specificity of GA and CAT, which do not allow their mutual treatment in the safety order. Future systems and methods should, therefore, be dedicated to the type of aviation. Additionally, according to the proposal to extend the SHELL model, they should be developed in at least three areas at the same time.

\section{Source materials}

[1] Analiza przewozów pasażerskich w polskich portach lotniczych w 2017 roku., Wyd. Urząd Lotnictwa Cywilnego, Wydział Statystyk i analiz, Warszawa, 2018.

[2] Cieślak E. Bezpieczeństwo w lotnictwie. Bezpieczeństwo i niezawodność w lotnictwie, Toruń, 2009.

[3] Fellner A., Osowski M. Uwzględnienie czynnika ludzkiego w analizie bezpieczeństwa procesu zarządzania zasobami ludzkimi. Problemy kryminalistyki, 2015, 290(4), 3545.

[4] Galant M. Ograniczanie ryzyka zagrożeń w lotnictwie ogólnym przez zastosowanie systemu monitorującego stan psychofizyczny pilota, Rozprawa Doktorska, Politechnika Poznańska, Poznań 2017.

[5] Galant M., Merkisz J. Analysis of the possibilities of using EEG in assessing pilots' psychophysical condition. Scientific Journal of Silesian University of Technology. Series Transport, vol. 95, pp. 39-46, 2017.

[6] Grochowski M. Wnioski z badań zdarzeń lotniczych prowadzonych przez Komisję Badania Wypadków Lotniczych Lotnictwa Państwowego. Bezpieczeństwo i niezawodność w lotnictwie, Toruń, 2009.

[7] International Civil Aviation Organization, Safety Management Manual, Doc. 9859 ICAO, Wyd. Urząd Lotnictwa Cywilnego, Warszawa, 2013.

[8] Klich E. Bezpieczeństwo lotów. Instytut Technologii Eksploatacji, Radom, 2011.

[9] Krajowy Program Bezpieczeństwa w Lotnictwie Cywilnym. Ministerstwo Infrastruktury i Budownictwa. Wyd. Urząd Lotnictwa Cywilnego, Warszawa, 2016.

[10]Lewandowski P. A. Statystyka Zdarzeń Lotniczych 2016/2017. Państwowa Komisja Badania Wypadków Lotniczych, Warszawa, 2018.

[11] Łuczak K. (red.). Zarządzanie bezpieczeństwem w lotnictwie cywilnym. Uniwersytet Śląski w Katowicach, Katowice, 2016.

[12] Makarowski R., Smolicz T. Czynnik ludzki w wypadkach lotniczych. Wyd. Adriana Aviation sp. z o.o., Kosowizna, 2012. 
[13] Merkisz J., Pielecha J., Markowski J., Galant M., Jasiński R., Gallas D. The analysis of air transport in Poland. International Conference on Air Transport INAIR 2015, Amsterdam, Holland, 2015.

[14]Razin P., Kruszewski M., Niezgoda M., Kamiński T. Wybrane metody detekcji stanów zmęczenia u osób kierujących pojazdami. Prace Naukowe Politechniki Warszawskiej, 114, 2016.

[15] UrbanyiPopiołek I. (red.). Ekonomiczne i organizacyjne aspekty transportu. Praca zbiorowa. Wydawnictwo Uczelniane Wyższej Szkoły Gospodarki w Bydgoszczy, Bydgoszcz, 2013.

[16] Ustawa z dnia 3 lipca 2002 r. (Dz.U. 2002 Nr 130 poz. 1112), Prawo Lotnicze. Warszawa, Kancelaria Sejmu, 2002. 